\title{
Perubahan lahan vegetasi berbasis citra satelit di DAS Citarum, Bandung, Jawa Barat
}

\author{
Teguh Husodo ${ }^{1,2,3}$, Yazid Ali ${ }^{3}$, Siti Rodiatan Mardiyah ${ }^{3}$, Sya Sya Shanida ${ }^{3 *}$, Oekan S Abdoellah ${ }^{2,3,4}$ dan Indri Wulandari ${ }^{1,2,3}$
}

${ }^{1}$ Departemen Biologi, Fakultas Matematika dan Ilmu Pengetahuan Alam, Universitas Padjadjaran. Jatinangor, Sumedang 45363, Jawa Barat.

${ }^{2}$ Program Pascasarjana Ilmu Lingkungan, Universitas Padjadjaran, Coblong, Bandung, Jawa Barat.

${ }^{3}$ Center of Environment and Sustainable Science, Universitas Padjadjaran, Coblong, Bandung 40132, Jawa Barat.

${ }^{4}$ Program Studi Antropologi, Fakultas Ilmu Sosial dan Politik, Universitas Padjadjaran, Jatinangor, Sumedang, Jawa Barat.

Koresponden Email: syasyashanida@gmail.com

Direvisi: 2020-12-23. Diterima: 2021-02-10

(C)2021 Fakultas Geografi UGM dan Ikatan Geograf Indonesia (IGI)

\begin{abstract}
Abstrak. DAS Citarum mengalami perubahan struktur lingkungan yang tinggi yang berakibat pada penurunan kualitas lingkungan, sehingga diperlukan gambaran mendetail mengenai kondisi perubahan lahan vegetasi di DAS Citarum. Tujuan dari penelitian ini untuk mengetahui proses perubahan luasan lahan vegetasi di DAS Citarum, Bandung, Jawa Barat. Penelitian ini menggunakan data penginderaan jauh dengan pendekatan kuantitatif. Pemetaan perubahan penutupan vegetasi di DAS Citarum menggunakan data citra Landsat multitemporal dengan perangkat lunak QGIS. Pada pelaksanaan penelitian ini, beberapa tahapan yang dilakukan, diantaranya pengolahan awal citra satelit (pre-processing), pengolahan citra digital (image processing), verifikasi data citra (NDVI), dan analisis perubahan penutupan lahan. Hasil studi menunjukkan bahwa terjadi penurunan luasan lahan vegetasi seluas 35\% pada tahun 1989 - 2019 dengan rata-rata penyusutan luas lahan sebesar $0.64 \%$ setiap tahunnya dan penyusutan terbesar pada tahun 2006. Penyusutan lahan cenderung terjadi pada wilayah yang berbatasan dengan Kota Bandung, yang diperkirakan sebagai bagian dari pengembangan wilayah kota kedaerah sekitarnya dan hasil menunjukkan wilayah yang mengalami penyusutan terbesar merupakan kecamatan dengan luas wilayah relatif kecil dibandingkan dengan wilayah kecamatan lainnya seperti Cipatat (74\%) dan Batujajar (83\%). Meski demikian, selama periode tahun 1989 - 2019, beberapa kecamatan menunjukkan peningkatan luas lahan bervegetasi seperti Kecamatan Bojongsoang, Slawi, dan Tanjungsari.
\end{abstract}

Kata kunci: Citra Satelit, Landsat, Penyusutan Lahan.

Abstract. The Citarum watershed undergoes a significant change in environmental structure, which results in a decrease in environmental quality, so a detailed description of the conditions of land change in vegetation in the Citarum watershed is needed. The main objective of this study: the process of changing the area of vegetation in the Citarum watershed, Bandung, West Java. This study uses remote sensing data with a quantitative approach. Mapping of land cover changes in the Citarum watershed uses multitemporal Landsat imagery with QGIS software. Several steps were carried out, including pre-processing, image processing, NDVI, and land cover change analysis. The study results show a decrease in the area of vegetation area of 35\% in 1989 - 2019, with an average shrinkage of the land area of $0.64 \%$ annually and the most extensive shrinkage in 2006. Land shrinkage tends to occur in areas bordering Bandung City, which is estimated as part of the city's development to the surrounding area. The most extensive shrinkage areas are the districts with relatively small areas compared to other sub-districts such as Cipatat (74\%) and Batujajar (83\%). However, during the period 1989 - 2019, several sub-districts showed an increase in vegetated land areas, such as Bojongsoang, Slawi, and Tanjungsari Districts.

Keywords: Satellite Imagery, Landsat, Land Shrinkage

\section{PENDAHULUAN}

Perubahan fungsi lahan merupakan salah satu faktor penting dalam penurunan kualitas lingkungan. Dalam dua dekade terakhir, Daerah Aliran Sungai (DAS) Citarum mengalami perubahan lingkungan sejalan dengan perkembangan wilayah, salah satunya penurunan kemampuan tangkapan air pada DAS Citarum akibat penebangan tegakan pohon pada kawasan hutan serta alih fungsinya menjadi lahan pertanian; rendahnya upaya konservasi lahan dalam budidaya dan perubahan peruntukkan lahan menjadi kawasan pemukiman yang tidak terkendali.

Paryono dkk. (2016) mengungkapkan adanya penurunan penggunaan lahan bervegetasi dan lahan pertanian di DAS
Citarum hilir, sedangkan penggunaan lahan non-vegetasi untuk pemukiman/ bangunan mengalami peningkatan dalam kurun waktu tahun 2000 - 2014. Ridwan dkk. (2017) menyebutkan terjadinya penurunan persentase lahan bervegetasi di DAS Citarum tahun 2000 - 2009, diantaranya lahan sawah sebesar $4.83 \%$, hutan primer $1.86 \%$, dan hutan sekunder 2.37\%. Selanjutnya, Yusuf dkk. (2018) mengemukakan bahwa DAS Citarum pada tahun 2014 didominasi oleh sawah seluas $26.06 \%$, lahan terbangun $22.9 \%$, sedangkan hutan sekunder hanya $8.367 \%$. Menurut Hidayat (2014) terjadinya perubahan tutupan dan penggunaan lahan di suatu DAS dapat mempengaruhi karakteristik hidrologi dan erosi 
pada DAS tersebut.

Perubahan lingkungan tersebut telah terjadi dalam kurun waktu yang lama, sehingga membutuhkan upaya pemulihan yang tidak sebentar. Salah satu faktor penting perubahan kondisi DAS Citarum yaitu faktor ekonomi yang juga belum mendapatkan pemecahan masalah. Menurut Kamusoko dkk. (2009), faktor sosial ekonomi merupakan pemicu terjadinya perubahan tutupan lahan, padahal pemahaman terhadap proses perubahan tutupan lahan terutama pada suatu DAS akan memberikan masukan terhadap optimalisasi rencana pengelolaan DAS itu sendiri.

Hingga saat ini, belum terdapat penelitian yang menunjukkan seberapa besar penyusutan lahan vegetasi di wilayah Citarum dalam kurun waktu yang lama. Hal tersebut dianggap penting karena dapat memberikan secara jelas apakah terdapat pola yang spesifik saat terjadinya penurunan vegetasi dan berapa besaran vegetasi yang menyusut pada waktu tertentu. Selain itu, dengan menganalisa penyusutan lahan jangka panjang, dapat diketahui rentang waktu terjadinya penyusutan paling signifikan, sehingga dapat diketahui penyebab utamanya, salah satunya dari aspek sosial dan ekonomi. Menurut Petit dkk. (2001) bahwa perkembangan perubahan tutupan lahan sangat penting untuk diketahui, agar pola perubahan tutupan lahan di masa yang akan datang dapat diprediksi, sehingga perubahan penutupan lahan yang bersifat negatif dapat dicegah atau dikurangi. Selain itu, dengan adanya gambaran perkembangan perubahan tutupan lahan dapat menjadi evaluasi dalam menerapkan suatu kebijakan daerah. Informasi penutupan lahan diperlukan untuk memantau perubahan penutupan dan penggunaan lahan, menentukan arah kebijakan pembangunan, perencanaan pengembangan wilayah, serta pengelolaan sumber daya alam (Nugroho, 2015).

Untuk menyelesaikan permasalahan yang berkaitan dengan perubahan tutupan lahan di DAS Citarum, diperlukan pendekatan yang komprehensif yaitu menggunakan penginderaan jauh. Teknologi penginderaan jauh mampu merekam permukaan bumi dalam cakupan yang luas, mudah diadopsi dan diintegrasikan dengan berbagai disiplin ilmu untuk mengkaji fenomena permukaan bumi, serta mengidentifikasi perubahan lingkungan berdasarkan penggabungan sumber data spasial yang saling berkaitan (Hadi, 2008). Perkembangan teknologi penginderaan jauh dimanfaatkan untuk keperluan perencanaan, pemantauan, dan evaluasi dalam berbagai sektor. Salah satu informasi yang diperoleh dari data penginderaan jauh adalah penutupan lahan (Hadi, 2008). Dengan menggunakan penginderaan jauh, perubahan tutupan vegetasi dapat dilakukan secara praktis dan ekonomis, terutama pada skala studi yang luas (Langley dkk., 2001; Nordberg \& Evertson, 2005).

\section{METODE PENELITIAN}

\section{Lokasi Penelitian}

Secara administratif, wilayah studi pada DAS Citarum hanya mencakup 71 kecamatan di tiga kabupaten/kota, yaitu Kabupaten Bandung, Kabupaten Bandung Barat, dan Kota Bandung, Jawa Barat (Gambar 1).

\section{Alat dan Bahan}

Untuk dapat memproses data - data spasial yang dibutuhkan dalam penelitian ini dipergunakan perangkat lunak open source Quantum Geographic Information System (QGIS versi 3.10) yang merupakan perangkat lunak yang berpayung pada

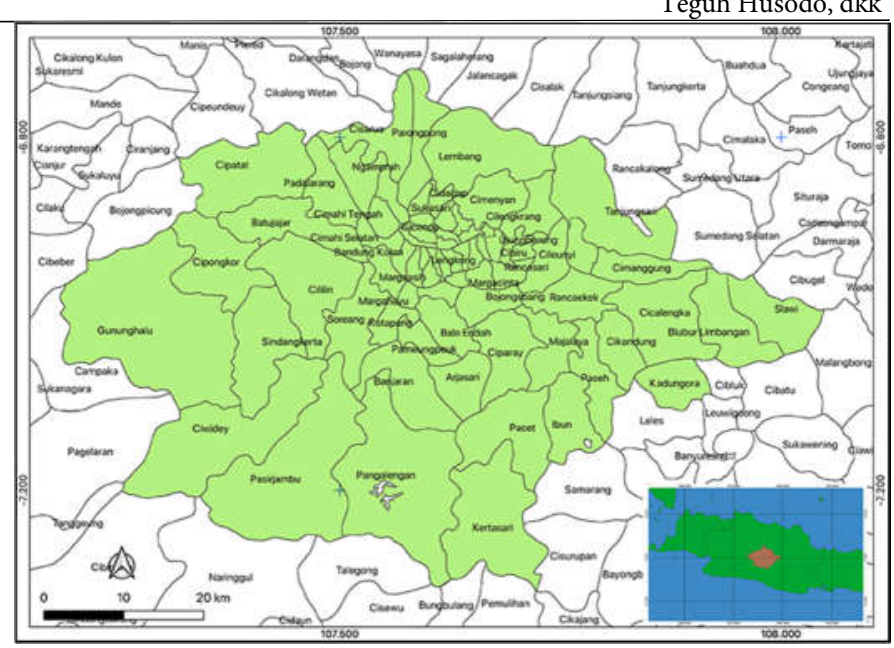

Gambar 1. Penyebaran Kecamatan Terhadap Wilayah DAS Citarum (Sumber: Analisis Pribadi, 2019)

General Public License (GNU). Keunggulan GIS adalah kemampuan untuk mempergunakan plugin Semi-automatic Classification (SCP), sehingga memungkinkan dilakukannya proses persiapan, pengolahan, dan analisa data - data spasial, khususnya proses klasifikasi terbimbing (Supervised Classification). Melalui plugin SCP, dimungkinkan dilakukannya evaluasi akurasi Supervised Classification.

SCP memiliki kompatibilitas berbagai data - data citra satelit, salah satunya adalah Landsat, yang ditambahkan untuk membaca data spektral yang dimiliki oleh Landsat. SCP juga menyediakan tiga pilihan algoritma untuk proses klasifikasi, diantaranya Minimum Distance, Maximum Likelihood, dan Spectral Angle Mapping, sehingga sangat cocok untuk dipergunakan pada penelitian ini (Purwanto dkk., 2020).

Bahan yang digunakan, yaitu data vektor batas wilayah kecamatan di Indonesia tahun 2015 format shp yang diperoleh dari Kementerian Lingkungan Hidup dan Kehutanan Republik Indonesia. Data raster yang digunakan adalah data citra satelit Landsat, yakni Landsat 4 dan 5, Landsat 7, dan Landsat 8. Masing - masing data yang diunduh memiliki dua scene, yaitu path/row 121/065 dan 122/065. Data yang diunduh memiliki tipe Level-1 Precision and Terrain Corrected Product (L1TP) yang memiliki radiometrik yang baik dan sudah terkalibrasi, serta ortorektifikasi menggunakan Ground Control Point (GCP), sehingga tidak diperlukan koreksi geometrik lagi (U.S. Geological Survey, 2016). Tabel 1 menunjukkan susunan data Landsat yang digunakan pada penelitian ini.

Hingga saat ini belum terdapat penelitian yang memberikan gambaran kondisi sungai Citarum serta perubahan lahan disekitarnya dari tahun kurang dari 1990 hingga tahun 2019 dengan interval waktu evaluasi perubahaan lahan dikisaran 3 tahunan yang diklasifikasi berdasarkan kecamatan. Dengan pendekatan tersebut maka akan dihasilkan informasi yang lebih komprehensif terkait kondisi proses perubahan lahan yang terjadi di wilayah Citarum, khususnya dari masing - masing Kecamatan.

Lebih lanjut informasi - informasi yang diperoleh dari pendekatan yang dilakukan diatas, akan dapat memberikan informasi yang dibutuhkan dalam melakukan berbagai kebijakan yang spesifik ditingkat Kecamatan. Jika dihubungkan dengan waktu proses data, juga akan diperoleh informasi yang dibutuhkan terkait apa kebijakan yang sedang dijalan- 
kan saat rentang waktu pengambilan data, sehingga mengakibatkan perubahan lahan di wilayah Citarum.

Tabel 1. Data Landsat untuk Analisa DAS Citarum

\begin{tabular}{ccc}
\hline Landsat 4 \& 5 TM & Landsat 7 & Landsat 8 \\
\hline Tahun 1989 & Tahun 2004 & Tahun 2013 \\
Tahun 1992 & Tahun 2006 & Tahun 2015 \\
Tahun 1998 & Tahun 2009 & Tahun 2019
\end{tabular}

Tahun 2001

Citra satelit Landsat cukup baik untuk menganalisis perubahan tutupan lahan pada area yang luas dalam kurun waktu yang lama. Citra Landsat memiliki resolusi spasial 30 $\mathrm{m}$, resolusi temporal 16 hari, dan memiliki orbit SunSynchronous pada ketinggian orbit $705 \mathrm{~km}$ (Cahyono dkk., 2019). Landsat merupakan satelit tertua sejak tahun 1972 dengan sensor Multispcetral Scanner (MMS). Setelah tahun 1982, dilakukan perbaikan dalam resolusi spasial, spektral, dan radiometrik dengan menempatkan sensor Thematic Mapper (TM) pada Landsat 4 dan Landsat 5 di tahun 1984. Keduanya memiliki 7 band spektral dengan resolusi spasial $30 \mathrm{~m}$ (Visible, NIR, MIR) dan $120 \mathrm{~m}$ (Thermal) (Suwargana, 2013; U.S. Geological Survey, 2016). Landsat 6 diluncurkan tahun 1993 dengan sensor Enchanced Thematic Mapper (ETM), namun gagal mencapai orbit. Hingga pada tahun 1999, Landsat 7 diluncurkan dengan instrumen ETM+, memiliki 8 band spektral dengan resolusi spasial $30 \mathrm{~m}$ (Visible, NIR, SWIR, MIR), $60 \mathrm{~m}$ (Thermal), dan $15 \mathrm{~m}$ (PAN), serta ukuran scene $180 \mathrm{~km} \times 185 \mathrm{~km}$. Landsat 7 mengalami kerusakan Scan Line Corrector (SLC) sejak tahun 2003 yang menyebabkan data citra tidak sempurna, meski demikian, Landsat 7 masih beroperasi sampai saat ini. Landsat 8 mulai beroperasi tahun 2013, dilengkapi dua sensor, yaitu Operational Land Imager (OLI) dengan 9 band spektral, dan Thermal Infrared Sensor (TIRS) dengan 2 band spektral. Kedua sensor menyediakan resolusi $30 \mathrm{~m}$ (Visible, NIR, SWIR), 100 $\mathrm{m}$ (Thermal), dan $15 \mathrm{~m}$ (PAN) (U.S. Geological Survey, 2016). Kerusakan pada sensor TIRS mendorong perbaikan dan peningkatan kualitas sensor dengan mengembangkan sensor TIRS-2 dan OLI-2 pada Landsat 9 yang direncanakan beroperasi pada 2021 (Masek dkk., 2020).

\section{Prosedur Penelitian}

Pada pelaksanaan penelitian ini, beberapa tahapan yang dilakukan, diantaranya pengolahan awal citra satelit (preprocessing), pengolahan citra digital (image processing), verifikasi data citra (NDVI), analisis perubahan penutupan lahan, evaluasi akurasi, ground check, dan reklasifikasi. Gambaran mengenai alur penelitian dapat dilihat pada Gambar 2.

\section{Pengolahan Awal Citra Satelit (Pre-processing)}

Untuk dapat menggunakan data Landsat dilakukan proses pengolahan awal data. Khusus data - data Landsat yang diunduh sejak tahun 2003, dilakukan proses penambalan data menggunakan pendekatan gap fill yang dilakukan dengan jarak feathering 50 piksel. Penggunaan feathering 50 piksel dilakukan dengan mempertimbangkan kelas lahan yang cenderung homogen, sehingga menghasilkan tutupan lahan yang cenderung halus transisi antara kelas lahan (Gaohong dkk. 2016).

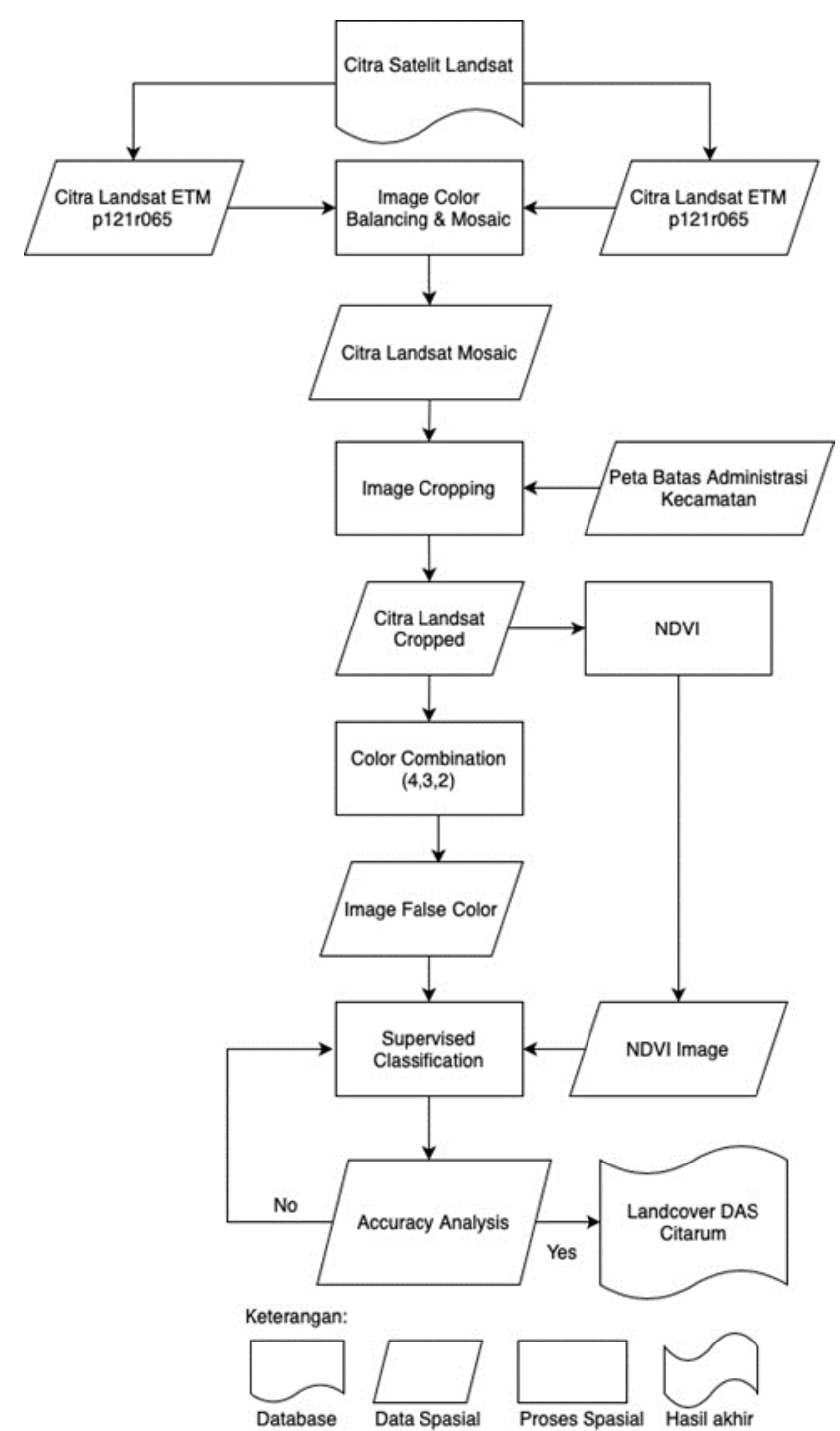

Gambar 2. Alur Penelitian

\section{Mosaik Citra Satelit}

Wilayah kajian Citarum merupakan wilayah perbatasan antara path121row065 dengan path122row065, sehingga diperlukan metodologi penggabungan antara dua area citra satelit tersebut. Selain menggabungkan citra satelit, juga dilakukan proses penyamaan kualitas kontras, sehingga menghasilkan satu kesatuan citra yang kohesif (dengan kontras bersifat konsisten, terorganisir, solid, dan interkoneksi pada koordinat).

\section{Koreksi Radiometrik}

Dilakukan proses perbaikan bias pada nilai digital atau nilai kecerahan piksel yang terukur pada data histogram yang diakibatkan oleh gangguan atmosfer maupun akibat kesalahan respon detektor. Koreksi terhadap gangguan atmosfer dalam penelitian ini dilakukan dengan menggunakan metode histogram minimum.

\section{Penyekatan Area Penelitian (Cropping)}

Setelah proses diatas, agar dapat mempersempit wilayah penelitian sesuai dengan wilayah kajian Citarum, maka dilakukan proses penyekatan ini menggunakan batas Citarum Hulu dari data vektor BPDAS Citarum Ciliwung. 
Intepretasi Citra Satelit secara Visual (Visual Image Interpretation)

Interpretasi ini dilakukan untuk mendeteksi dan mengidentifikasi objek yang ada di permukaan bumi dan tampak pada citra dengan mengenali dasar karakter spasial, spektral, maupun temporal. Interpretasi ini dilakukan dengan menggabungkan band - band yang terdapat pada citra satelit Landsat, yakni band 4, 3, dan 2. Interpretasi visual citra dilakukan berdasarkan karakteristik visual pada citra seperti warna, bentuk, ukuran, pola, tekstur, bayangan, dan asosiasi.

\section{Pengolahan Citra Digital (Image Processing)}

Klasifikasi secara terbimbing (Supervised Classification)

Metode Supervised Classification adalah metode yang paling banyak dilakukan untuk proses klasifikasi citra digital, karena dapat menggabungkan antara interpretasi manusia dengan bantuan aplikasi, sehingga proses dapat lebih dikontrol. Penelitian ini menggunakan lima kelas klasifikasi lahan, diantaranya vegetasi, non-vegetasi, air, awan, dan bayangan awan. Metode ini menggunakan pengelompokkan piksel - piksel untuk menentukan suatu jenis lahan yang memiliki kemiripan rentang spektral yang ada.

Area Contoh (Training Area) dengan menggunakan NDVI

Pengambilan contoh dilakukan berdasarkan data yang diperoleh dari nilai NDVI, dimana rentang NDVI akan menentukan apakah suatu wilayah memiliki nilai penutupan yang didominasi oleh vegetasi atau tidak. Rentang nilai NDVI dari -1 hingga +1 merupakan rentang nilai yang dimiliki oleh citra satelit. Nilai yang mendekati +1 mengindikasikan bahwa lahan tersebut didominasi oleh penutupan vegetasi, nilai yang mendekati angka 0 mengindikasikan bahwa lahan tersebut merupakan wilayah non-vegetasi, sementara nilai yang mendekati -1 mengindikasikan bahwa lahan tersebut didominasi oleh air.

\section{Analisis Perubahan Penutupan Lahan}

Setelah diketahui hasil dari klasifikasi citra Landsat secara tahun ke tahun dengan mengunakan metode maximum likelihood, maka dilakukan analisis perubahan penutupan lahan tersebut. Analisis perubahan penutupan lahan dilakukan dengan menggunakan overlay (tumpangtindihkan) citra satelit Landsat (tahun 1989, 1992, 1998, 2001, 2004, 2005, 2009, 2013, 2015, 2019) dengan batas administrasi kecama$\tan$.

Teknik overlay multitemporal citra satelit memungkinkan perekaman suatu area oleh sensor dari waktu yang berbeda-beda, sehingga dapat digunakan untuk menganalisis perubahan lingkungan termasuk perubahan tutupan lahan (Hadi, 2008) dan perubahan luas tutupan lahannya (Eddy dan Dian, 2018). Dalam pemanfaatannya, teknik overlay multitemporal dapat digunakan untuk menganalisis perubahan kerapatan vegetasi dan luasannya (Irawan dan Sirait, 2017; Romiyanto dkk., 2015), perubahan tutupan lahan area

Tabel 2. Kappa Accuracy

\begin{tabular}{|c|c|c|c|c|c|c|}
\hline \multirow{2}{*}{$\begin{array}{c}\text { Data Acuan Training } \\
\text { Area }\end{array}$} & \multicolumn{4}{|c|}{ Disklasifikasi Kelas (Data Klasifikasi pada Peta) } & \multirow{2}{*}{ Total Baris } & \multirow{2}{*}{$\begin{array}{r}\text { Producer } \\
\text { Accuracy }\end{array}$} \\
\hline & $\mathrm{A}$ & $\mathrm{B}$ & $\mathrm{C}$ & $\mathrm{D}$ & & \\
\hline $\bar{A}$ & $\mathrm{X}_{11}$ & $\mathrm{X}_{12}$ & $\mathrm{X}_{13}$ & $\mathrm{X}_{14}$ & $\mathrm{X}_{1+}$ & $\mathrm{X}_{11} / \mathrm{X}_{1+}$ \\
\hline B & $\mathrm{X}_{21}$ & $\mathrm{X}_{22}$ & $\mathrm{X}_{23}$ & $\mathrm{X}_{24}$ & $\mathrm{X}_{2+}$ & $\mathrm{X}_{21} / \mathrm{X}_{2+}$ \\
\hline $\mathrm{C}$ & $\mathrm{X}_{31}$ & $\mathrm{X}_{32}$ & $\mathrm{X}_{33}$ & $\mathrm{X}_{34}$ & $\mathrm{X}_{3+}$ & $\mathrm{X}_{31} / \mathrm{X}_{3+}$ \\
\hline $\mathrm{D}$ & $\mathrm{X}_{41}$ & $\mathrm{X}_{42}$ & $\mathrm{X}_{43}$ & $\mathrm{X}_{44}$ & $\mathrm{X}_{4+}$ & $\mathrm{X}_{41} / \mathrm{X}_{4+}$ \\
\hline Total Kolom & $\mathrm{X}_{+1}$ & $\mathrm{X}_{+2}$ & $\mathrm{X}_{+3}$ & $\mathrm{X}_{+4}$ & $\mathrm{~N}$ & \\
\hline User's Accuracy & $\mathrm{X}_{11} / \mathrm{X}_{+1}$ & $\mathrm{X}_{12} / \mathrm{X}_{+2}$ & $\mathrm{X}_{13} / \mathrm{X}_{+3}$ & $\mathrm{X}_{14} / \mathrm{X}_{+4}$ & & \\
\hline
\end{tabular}

$$
\begin{gathered}
\text { Kappa accuracy }=\frac{N \Sigma_{i}^{\top} X_{i i}-\Sigma_{i}^{T} X_{i+} X_{+i}}{N^{2}-\Sigma} \times 100 \% \\
X_{i+} X_{+i} \\
\text { User's accuracy }=\frac{X_{i i}}{X_{+i}} \times 100 \% \\
\text { Producer'saccuracy }=\frac{X_{i i}}{X_{i+}} \times 100 \% \\
\text { Overall accuracy }=\frac{N \Sigma_{i}^{\prime} X_{i i}}{N} \times 100 \%
\end{gathered}
$$

Keterangan:

$\mathrm{N}=$ Jumlah piksel yang digunakan dalam contoh

$\mathrm{r}=$ Jumlah baris atau kolom pada matriks kesalah (jumlah kelas)

$\mathrm{X}_{\mathrm{i}+}=$ Jumlah piksel dalam baris ke-i

$\mathrm{X}_{+\mathrm{I}}=$ Jumlah piksel dalam kolom ke-i

$\mathrm{X}_{\mathrm{ii}}=$ Nilai diagonal dari matriks kontingensi baris ke-I dan kolom ke-i 
DAS dan pergeseran garis pantai (Kasim, 2012), perubahan pola alur sungai (Kurniawan, 2020), hingga menyusun model spasial untuk mitigasi bencana (Lusy dkk., 2020).

\section{Evaluasi Akurasi}

Evaluasi hasil dilakukan untuk melihat besarnya kesalahan klasifikasi area contoh, sehingga dapat ditentukan berapa besar persentase ketelitian pemetaan. Pada penelitian ini dilakukan analisa akurasi dengan menggunakan matriks kesalahan (confusion matrix). Ketelitian tersebut meliputi jumlah piksel area contoh yang diklasifikasikan dengan benar atau salah. Semi-automatic Classification (SCP) menyediakan tools yang dapat dipergunakan untuk menentukan titik - titik acak dalam melakukan analisa akurasi hasil klasifikasi lahan.

Kami menggunakan dua pendekatan dalam melakukan proses evaluasi akurasi klasifikasi lahan, yakni dengan menggunakan nyata daratan (ground check) dan interpretasi lahan mempergunakan citra satelit beresolusi tinggi (google maps). Dari masing - masing titik yang telah ditentukan sebagai lokasi evaluasi lahan, maka dilakukan pengecekan apakah wilayah - wilayah tersebut telah sesuai atau tidak dengan hasil klasifikasi yang telah ditentukan.

Dalam penelitian ini, kami menggunakan dua pendeka$\tan$ evaluasi akurasi, yakni user's accuracy dan producer's accuracy. Kedua evaluasi akurasi tersebut merupakan penentuan yang diperlukan untuk overall accuracy dan kappa accuracy (Megandana, 2013). Dalam memastikan hasil analisa, maka ditentukan kappa accuracy yang dipergunakan ${ }^{3} 85 \%$ dimana nilai tersebut merupakan nilai yang ditentukan oleh USGS (Tabel 2) (USGS, 2016).

\section{Pemeriksaan Lapangan (Ground Check)}

Pemeriksaan lapangan dilakukan untuk memperoleh informasi terkait kondisi yang terdapat di lapangan sebagai langkah evaluasi akurasi setelah melakukan Supervised Classification. Pemeriksaan lapangan ini dilakukan dengan menelusuri lokasi - lokasi pengamatan yang telah ditentukan yang disertai dengan dokumentasi penutupan lahan yang ada.

\section{Reklasifikasi}

Reklasifikasi merupakan kegiatan pengkelasan kembali data atribut dengan memecah bagian dari boundary dan menyatukannya dalam poligon baru yang telah direklasifikasi. Reklasifikasi dilakukan secara manual. Data direklasifikasi berdasarkan input pengguna, yakni karakteristik visual citra, hasil klasifikasi citra digital, dan pengamatan di lapangan.

\section{HASIL DAN PEMBAHASAN}

Berdasarkan data Landsat yang berhasil dikumpulkan, dari tahun 1989 - 2019 diperoleh karakteristik citra satelit dengan penutupan awan yang berbeda - beda (Tabel 3). Penutupan awan dapat dipengaruhi berbagai hal, diantaranya cuaca saat pengambilan data citra satelit dan area pengambilan citra satelit. Cuaca hujan akan memiliki penutupan awan yang lebih tinggi dibandingkan dengan cuaca panas. Area yang didominasi dengan penutupan air juga akan cenderung memiliki penutupan awan yang lebih besar. Kondisi tersebut mengakibatkan perlu adanya penentuan besaran presentase yang dapat ditoleransi saat penentuan data Landsat yang dapat digunakan, yakni $£ 5 \%$, sehingga dapat memberikan informasi yang lebih informatif ketika dilakukan proses analisa perubahan lahan di wilayah kajian (Wang dkk. 2019).

Secara umum, komposisi hasil klasifikasi lahan pada keseluruhan data Landsat tergambarkan pada Gambar 3. Komposisi lahan yang diperoleh sangat dipengaruhi oleh cuaca yang terjadi saat dilakukan perekaman data Landsat. Ketika data yang direkam terjadi pada kurun waktu penghujan, maka dapat dipastikan terjadi peningkatan luasan badan air. Peningkatan luasan badan air juga terjadi ketika wilayah - wilayah persawahan memasuki masa penanaman awal.

Berdasarkan analisis data dari citra antara tahun 1989 2019, terjadi penyusutan luas lahan bervegetasi di DAS Citarum. Hasil analisis statistika menunjukkan adanya hubungan regresi antara kelas lahan vegetasi dan non-vegetasi, bahwa

Tabel 3. Persentase Distribusi Penutupan Awan

\begin{tabular}{cccccccccccc}
\hline $\begin{array}{c}\text { Tahun } \\
\text { Perekaman }\end{array}$ & 1989 & 1992 & 1995 & 1998 & 2001 & 2004 & 2006 & 2009 & 2013 & 2015 & 2019 \\
\hline $\begin{array}{c}\text { Penutupan } \\
\text { Awan }\end{array}$ & $5,0 \%$ & $1,3 \%$ & $2,0 \%$ & $1,4 \%$ & $0,4 \%$ & $1,1 \%$ & $0,7 \%$ & $0,3 \%$ & $1,6 \%$ & $4,0 \%$ & $0,5 \%$ \\
\hline
\end{tabular}

Sumber: Analisis Pribadi (2019)

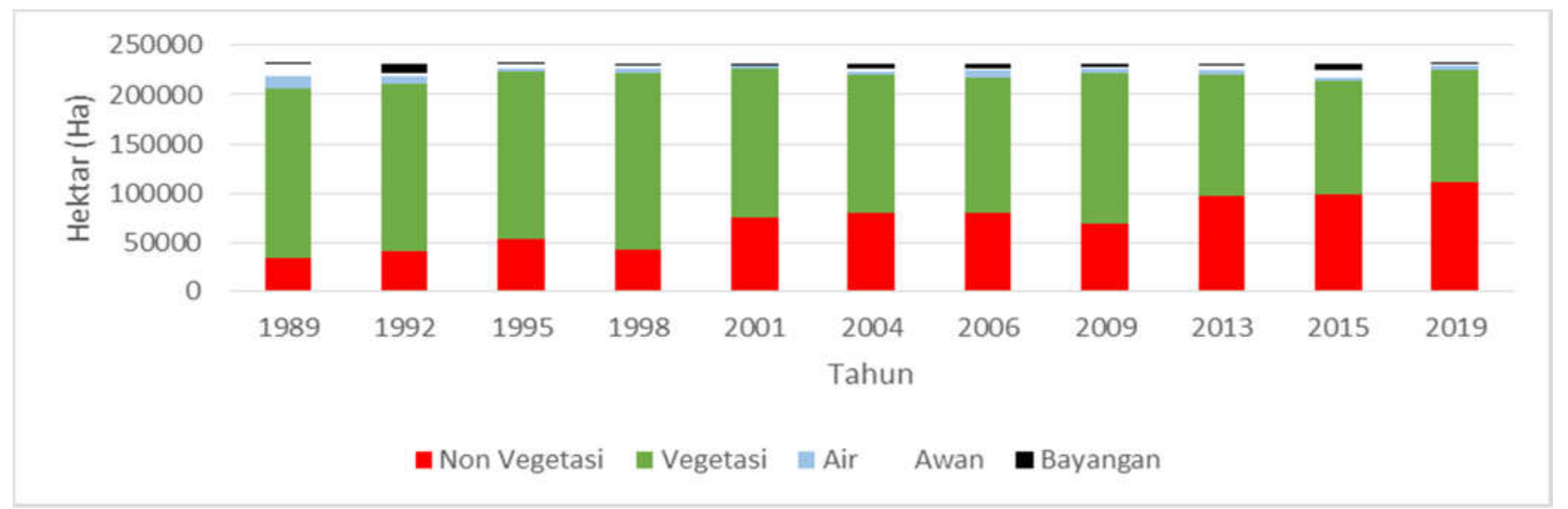

Gambar 3. Komposisi Lahan di Wilayah DAS Citarum dari Tahun 1989 - 2019 (Sumber: Analisis Pribadi, 2019) 
hilangnya lahan vegetasi dapat langsung terindikasi dari terjadinya perubahan fungsi lahan menjadi non-vegetasi. Sebagai gambaran umum, perubahan tutupan lahan bervegetasi disajikan pada Gambar 4. Perubahan lahan vegetasi menyusut secara dinamis dari tahun 1989 - 2019. Perubahan tersebut ditinjau dari aspek wilayah administrasi kecamatan yang terjadi pada beberapa wilayah kecamatan, yakni Kecamatan Bojongsoang, Margacinta, Rancasari, Cileunyi, Rancaekek, Majalaya, dan Ciparay.

Hasil studi menunjukkan bahwa perubahan yang terjadi secara fluktuatif adalah tata guna budidaya yang diolah secara intensif, yaitu lahan pertanian/sawah. Karakteristik lahan sawah dengan siklus 3 - 4 bulan mempengaruhi nilai indeks NDVI cukup tinggi ketika tanaman padi berumur dewasa, sehingga dapat ditetapkan apakah termasuk kedalam kawasan dengan lahan tegakan bervegetasi (tegakan hijau tahunan) atau sementara sebagai pertimbangan dalam analisis dukungan dari setiap tutupan lahan terhadap ekosistem DAS Citarum. Uji akurasi ataupun validasi dari proses $\mathrm{Su}$ pervised Classification ditampilkan pada Tabel 4.

Akurasi yang dihasilkan dari proses Supervised Classification dapat diterima dengan mempertimbangkan hasil yang diperoleh berkisar > 80\% (Megandana, 2013). Konsistensi tingkat akurasi ini dipengaruhi oleh salah satunya, sedikitnya kelas lahan yang dipergunakan dalam penelitian ini, dimana kelas lahan yang dipergunakan hanya lima kelas lahan saja. Sementara, kelas lahan yang dipergunakan lebih banyak lagi, maka akan mempengaruhi keakuratan evaluasi lahan yang

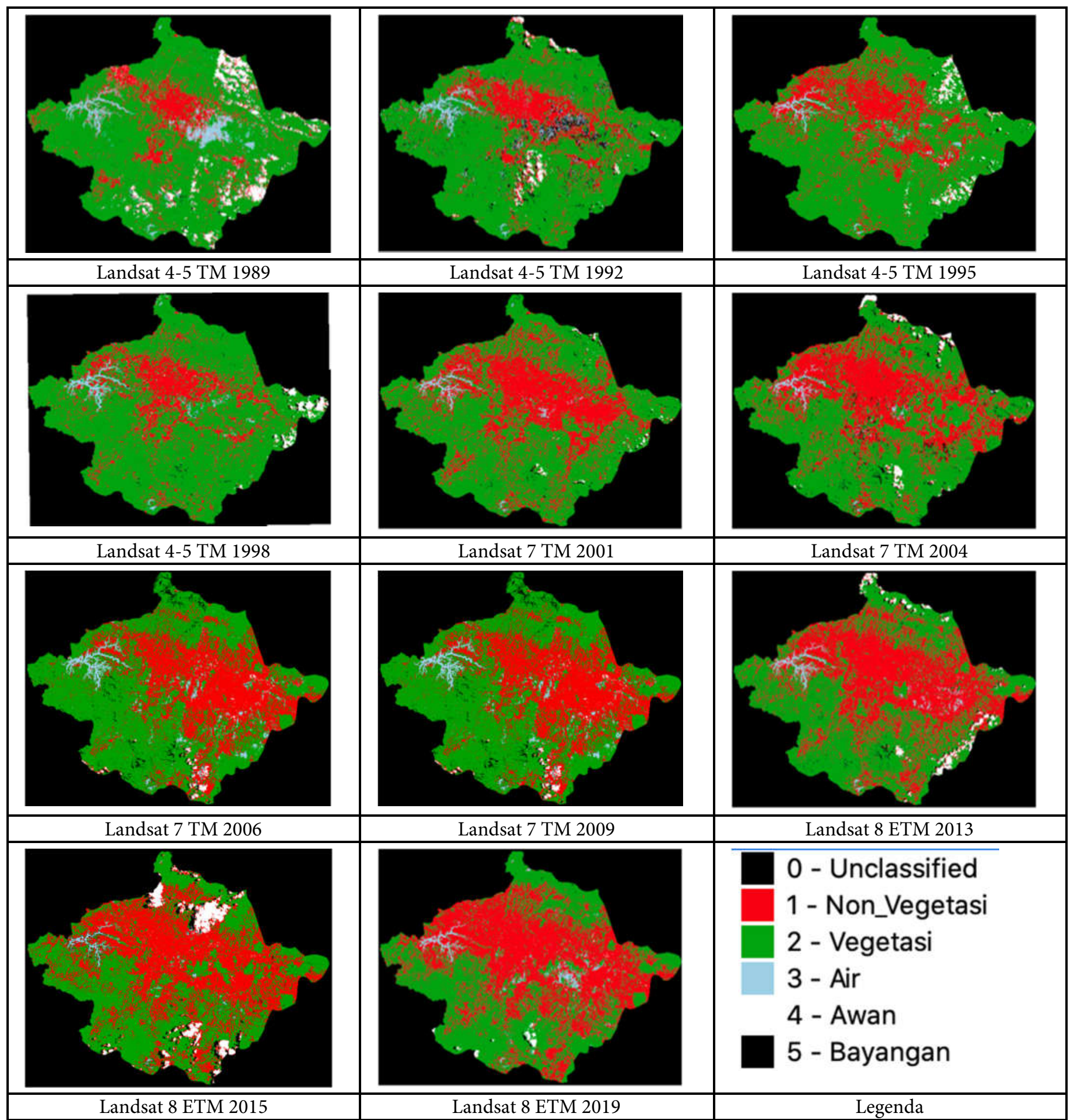

Gambar 4. Perubahan Luasan Vegetasi di Wilayah DAS Citarum (Sumber: Analisis Pribadi, 2019)

Hasil studi menunjukkan bahwa perubahan yang terjadi secara fluktuatif adalah tata guna 
dihasilkan.

Beberapa kasus yang paling signifikan dari menurunnya persentase akurasi adalah diakibatkan perubahan lahan yang awalnya merupakan kelas lahan vegetasi menjadi nonvegetasi dan begitupula sebaliknya. Hal tersebut dipengaruhi oleh kelas lahan yang merupakan lahan olahan, seperti sawah atau perkebunan, dimana ketika lahan dikategorikan sebagai lahan vegetasi, pada saat tersebut vegetasi olahan sedang dalam umur dewasa. Ketika lahan tersebut dikategorikan sebagai lahan non-vegetasi, maka pada waktu tersebut lahan sedang dalam fase pasca panen.

Sulitnya kelas lahan air memperoleh nilai $100 \%$, karena dipengaruhi adanya lahan olahan, khsusunya sawah. Dimana dalam proses penanamannya merupakan lahan yang memiliki intensitas air tinggi, sehingga dikategorikan sebagai lahan dengan penutupan air, sementara untuk tahun - tahun selanjutnya, lahan tersebut dikategorikan sebagai lahan vegetasi, atau bahkan menjadi lahan non-vegetasi.

Dari data yang telah diperoleh menggunakan user accuracy dan producer accuracy, selanjutnya menghitung Kappa Coefficient (Tabel 5) untuk memperoleh akurasi data secara keseluruhan yang diperoleh dengan menggunakan hasil klasifikasi yang telah dibuat lihat Tabel 5.

Tabel 5. Kappa Coefficient (\%)

Tahun Data Landsat

$\begin{array}{ll}1989 & 93,5 \\ 1992 & 95,5 \\ 1995 & 95,0 \\ 2001 & 94,0 \\ 2004 & 94,7 \\ 2006 & 92,9 \\ 2009 & 94,8 \\ 2013 & 91,9 \\ 2015 & 88,6 \\ 2019 & 91,3\end{array}$

Dari hasil yang telah dikalkulasi, terlihat bahwa seluruh data yang telah dilakukan pengklasifikasian, telah memberikan nilai yang sesuai dengan ketentuan yang diberikan oleh USGS dimana nilai persentase yang dihasilkan $>80 \%$. Nilai yang cukup rendah berada pada tahun 2015, dimana nilai tersebut dapat dipengaruhi oleh penutupan awan yang cukup besar, yankni $4 \%$, namun tetap dalam kondisi yang masih bisa diterima (Salgado dkk., 2019).

Seperti telah dijelaskan pada paparan sebelumnya bahwa terdapat beberapa kecamatan yang mengalami kenaikan luas tutupan lahan bervegetasi meskipun tidak konsisten, yaitu Kecamatan Bojongsoang, Slawi, dan Tanjungsari dibandingkan 68 kecamatan lainnya. Mengacu kepada pola perubahan lahan yang terjadi, proses penambahan lahan juga mengindikasikan perubahan tersebut terjadi pada lahan budidaya.

Berdasarkan data selama 20 tahun terakhir dari kondisi DAS Citarum, pada tahun 1989, DAS Citarum memiliki luas penutupan bervegetasi seluas 173.350 ha $(37,5 \%)$ dari luas tutupan lahan DAS seluas 462.709 ha, sedangkan pada tahun 2019 luas tutupan lahan bervegetasi tersisa $24,37 \%$ menyusut lebih dari 10\% dibandingkan tahun 1989 atau setara dengan 60.740 ha. Menurut Siliwangi (2014) bahwa pada tahun 2000 - 2009, tutupan hutan di DAS Citarum mengalami penurunan drastis sebesar $98 \%$ atau hanya tersisa $1,4 \%$ tutupan lahan bervegetasi dari total luasan DAS Citarum (716.372 hektar). Sebaliknya, luas pemukiman semakin bertambah pesat, dari 81.685 hektar pada tahun 2000 menjadi 176.441 hektar pada tahun 2009 dan masih pada kurun waktu yang sama, luas sawah bertambah dari 244.662 hektar menjadi 262.034 hektar dan luas perkebunan dari 123.154 hektar menjadi 240.470 hektar. Indikasi ini menunjukkan bahwa terjadi alih fungsi lahan dari lahan dengan tutupan tegakan vegetasi menjadi lahan budidaya intensif, seperti kebun dan sawah serta perkembangan pemukiman/ perkampungan. Mengacu kepada penelitian Yusuf, dkk. (2018) diketahui bahwa pada periode tahun 2014 dan prediksi pada tahun 2030, jenis tutupan lahan kebun/tegalan dan ladang/tegalan akan mengalami penurunan dan berbanding lurus dengan meningkatnya jenis tutupan terbangun, yaitu mencapai $1,0 \%-1,5 \%$.

Hasil analisis menunjukkan data bahwa pada 71 kecamatan, setidaknya terjadi penyusutan tutupan lahan bervegetasi seluas 3.000 ha $(0.64 \%)$ setiap tahunnya. Penyusutan tutupan lahan bervegetasi terbesar terjadi pada tahun 2006. Berbagai perubahan lahan yang dilakukan, diantaranya pemukiman, infrakstruktur, lahan olahan, atau bahkan hanya lahan terbuka rerumputan. Keseluruhan jenis penggunaan lahan tersebut tidak akan bisa mengakomodasi dukungan yang dibutuhkan oleh DAS Citarum, sehingga proses degradasi kualitas Sungai Citarum terus mengalami penurunan.

Menurut Hidayat (2014) bahwa perubahan tutupan lahan di suatu DAS dapat mempengaruhi karakteristik hidrologi DAS tersebut. Salim dkk. (2019) menunjukkan bahwa perubahan tersebut juga terjadi pada DAS Citarum hulu. Perubahan dari jenis tutupan lahan yang memiliki evapotranspirasi rendah menjadi tutupan lahan dengan evapotranspirasi tinggi menyebabkan terjadinya penurunan aliran sungai tahunan (Prasena \& Shrestha, 2013). Menurut Salim dkk. (2019) bahwa tutupan vegetasi maupun penggunaan lahan dapat mempengaruhi besarnya air larian karena tiaptiap jenis tutupan lahan akan memberikan respon yang berbeda terhadap curah hujan. Tutupan berupa hutan dengan tajuk, cabang/ranting, perakaran bahkan serasah dapat memperlambat laju aliran permukaan dan menahan air lebih lama di atas permukaan tanah, sehingga dapat terinfiltrasi terlebih dahulu.

Secara keseluruhan, dari tahun 1989 - 2019 terjadi penurunan lahan seluas 35\%. Diasumsikan bahwa persentase penurunan lahan $>35 \%$, karena ada beberapa bagian wilayah yang tertutupi oleh lahan olahan. Penyebaran penyusutan lahan terjadi secara merata di seluruh kecamatan, namun sentralisasi penyusutan lahan terjadi di wilayah terdekat dengan Kota Bandung. Persentase penyusutan dapat dilihat pada Gambar 5, dimana wilayah penutupan berwarna tua adalah wilayah kecamatan yang memiliki penyusutan wilayah tertinggi.

Secara visual, hampir sebagian besar wilayah yang mengalami penyusutan terbesar adalah wilayah - wilayah dengan luasan lahan yang kecil. Beberapa wilayah dengan luasan yang cukup besar, yakni Cipatat (2.146 hektar) dengan per- 
sentase penyusutan vegetasi sebesar 74\% dan Batujajar (7.299 hektar) dengan persentase penyusutan vegetasi sebesar $83 \%$. Wilayah - wilayah lainnya yang berwarna merah muda, memiliki tendensi perubahan fungsi lahan vegetasi yang lebih kecil dibandingkan dengan wilayah - wilayah kecamatan lainnya. Dapat dilihat dari Gambar 6 bahwa hal yang berbanding terbalik dengan Gambar 5 dimana penyusutan lahan vegetasi justru terjadi paling banyak di wilayah luar Kota Bandung. Sebanyak tiga kecamatan yang mengalami penyusutan luasan lahan vegetasi $>3.000$ hektar, yakni Kecamatan Batujajar, Cicalengka, dan Cililin. Kecamatan yang mengalami penyusutan pada kisaran 2.000 - 3.000 hektar adalah Kecamatan Cikandung, Cipongkor, Kertasari, Maja- laya, Rancaekek, dan Soreang. Sembilan kecamatan tersebut merupakan kecamatan dengan kontribusi terbesar dalam keseluruhan proses penyusutan lahan vegetasi yang terjadi di DAS Citarum.

Untuk dapat memastikan perubahan fungsi lahan vegetasi berhubungan dengan non-vegetasi, maka dilakukan proses analisa korelasi (Gambar 7). Fluktuasi antara penutupan lahan vegetasi dan lahan non-vegetasi cukup erat kaitannya, sehingga dapat dipastikan tidak dipengaruhi oleh tiga kelas lahan lainnya, yakni air, awan, dan bayangan.

Selain itu, hubungan antara vegetasi dan non-vegetasi dapat dilihat dari fungsi regresi yang dihasilkan dari tahun 1989 - 2019 (Gambar 8).

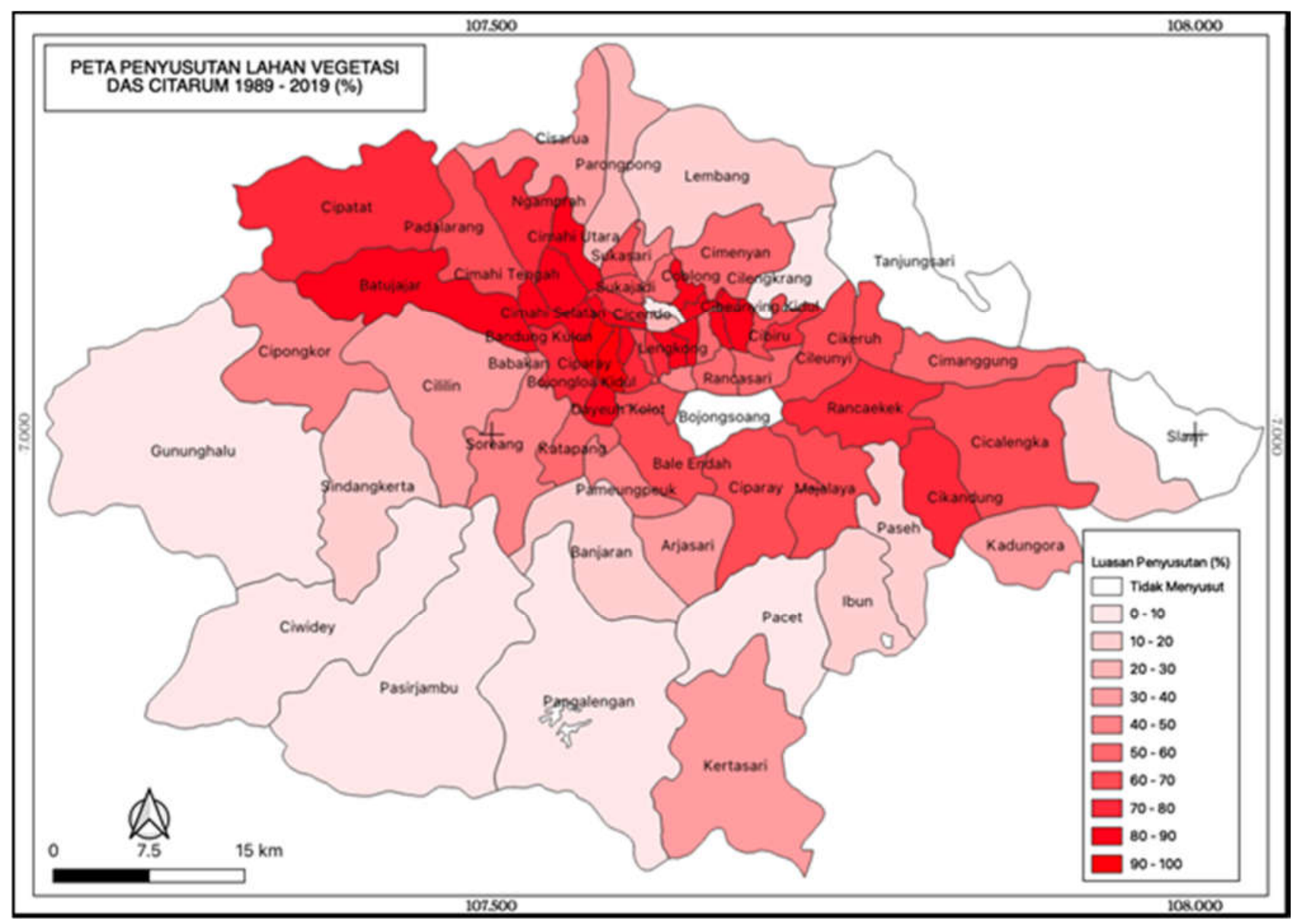

Gambar 5. Penyusutan Lahan Vegetasi DAS Citarum 1989 - 2019 (Sumber: Analisis Pribadi, 2019)

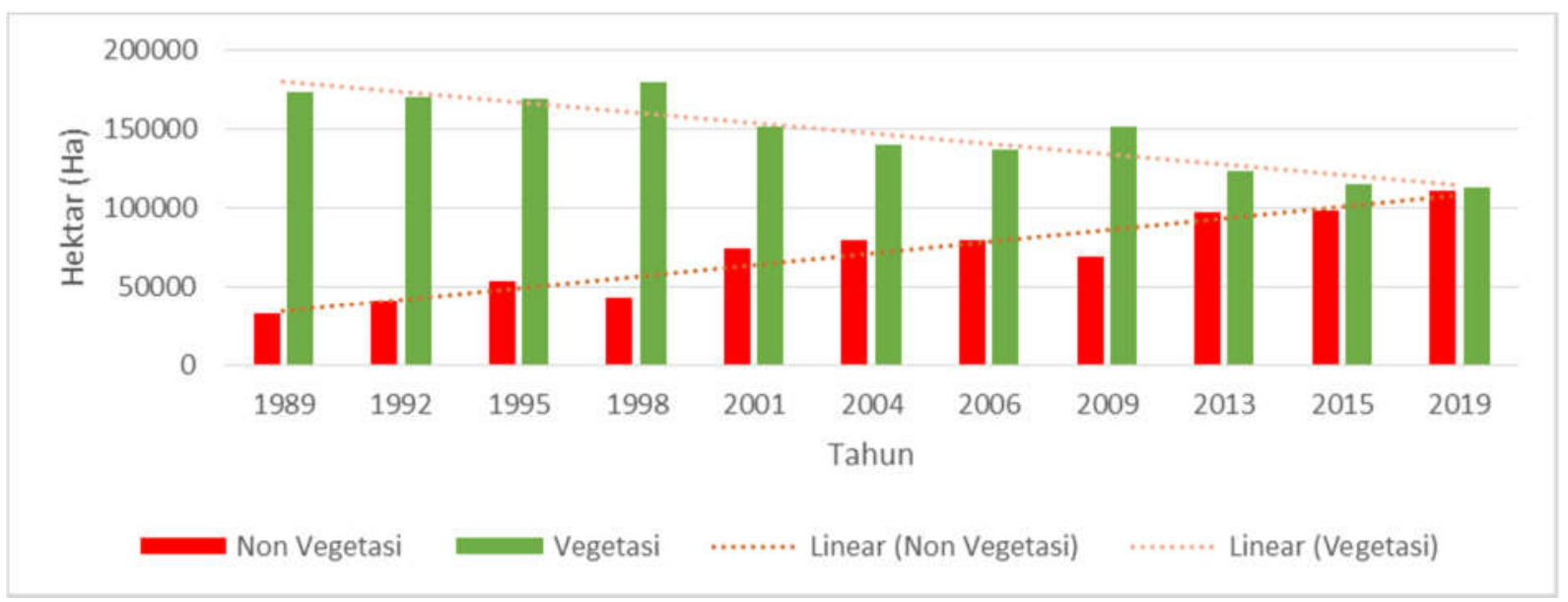

Gambar 7. Korelasi Penyusutan Lahan Vegetasi menjadi Non-vegetasi a(Sumber: Analisis Pribadi, 2019) 


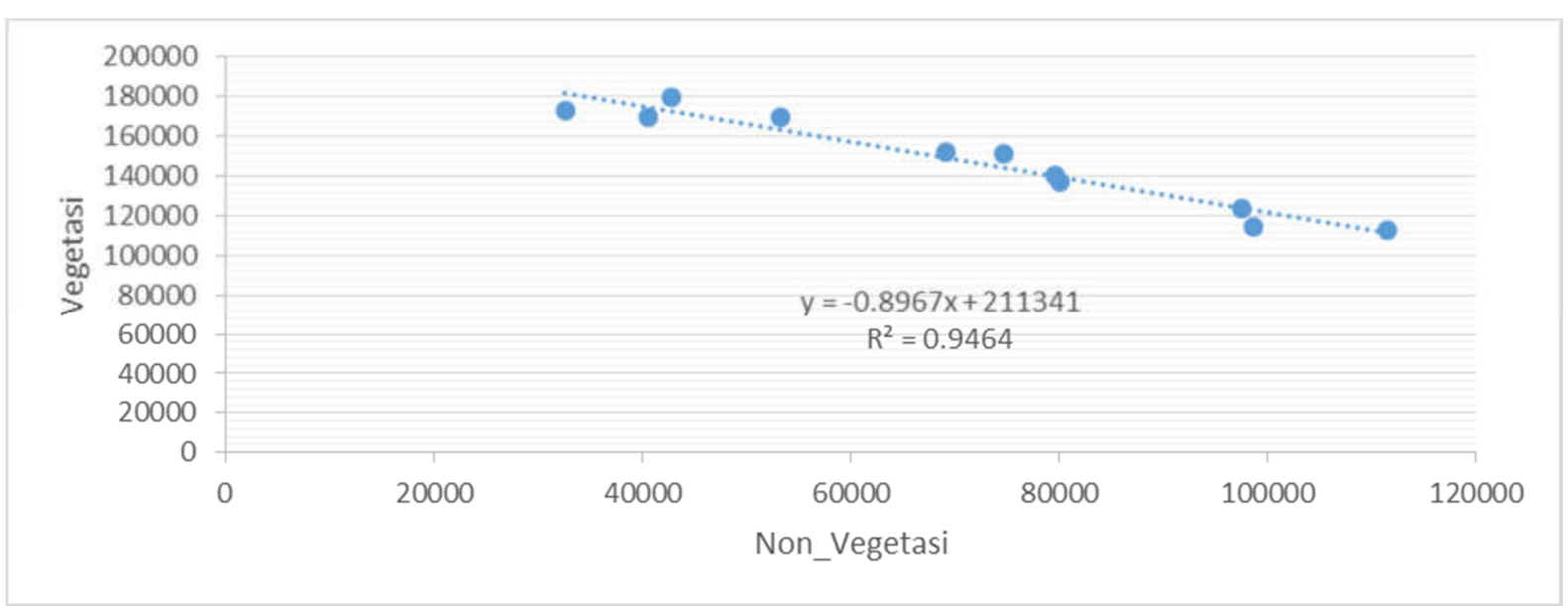

Gambar 8. Korelasi Antara Kelas Lahan Vegetasi dan Non-vegetasi (Sumber: Analisis Pribadi, 2019)

Analisa hubungan antara kedua kelas lahan tersebut ternyata sangat erat, dimana $\mathrm{R}^{2}$ yang dihasilkan sebesar 0.9464 . Hubungan yang erat tersebut juga menghasilkan fungsi $\mathrm{Y}$ yang dapat digunakan untuk memprediksi kemungkinan yang terjadi diantara kedua kelas lahan tersebut, yakni

$Y=-0.8967 x+211341$ .5

Keterangan: $\mathrm{Y}=$ Luasan vegetasi; $\mathrm{X}=$ Luasan non-vegetasi

Fungsi Y yang dihasilkan dapat melakukan prediksi untuk memastikan bahwa ketika terjadi peningkatan lahan non -vegetasi, maka kemungkinan terjadi penyusutan fungsi tutupan vegetasi dengan luasan sekian hektar. Informasi ini sangat penting untuk memprekdisi terjadinya penyusutan lahan dari tahun ke tahun.

\section{KESIMPULAN}

Penyusutan luasan lahan vegetasi di DAS Citarum terjadi secara signifikan selama 20 tahun terakhir, dengan persentase penyusutan lahan sebesar 35\%. Dari 71 kecamatan di Bandung, tiga kecamatan mengalami penambahan luasan lahan vegetasi di DAS Citarum, seperti Kecamatan Bojongsoang, Slawi, dan Tanjungsari. Sebagian besar wilayah yang mengalami penyusutan lahan vegetasi terbesar merupakan wilayah dengan luasan lahan kecil, seperti Kecamatan Cipatat dan Batujajar dengan persentase $83 \%$. Penyusutan luasan lahan vegetasi tersebar merata pada 71 kecamatan, namun terpusat pada wilayah terdekat dengan Kota Bandung. Sebagian besar penyusutan luasan lahan vegetasi ini diindikasikan adanya alahan olahan, khususnya lahan sawah.

\section{UCAPAN TERIMA KASIH}

Apresiasi diberikan kepada Prof. Oekan S. Abdoellah dalam Program ALG (Academic Leadership Grant) Universitas Padjadjaran. Apresiasi diberikan pula kepada tenaga ahli/tim peneliti dan tim surveyor dalam pelaksanaan riset ini. Penelitian ini didanai oleh Hibah Riset Internal Universitas Padjadjaran dengan Nomor: 1427/UN6.3.1/LT/2020.

\section{KONTRIBUSI PENULIS}

Penulis pertama melakukan pengumpulan data dan menyusun laporan riset; Penulis kedua melakukan penulisan metode penelitian dan hasil penelitian; Penulis ketiga, keempat, kelima, dan keenam melakukan review naskah publikasi.

\section{DAFTAR PUSTAKA}

Cahyono, B.E., Frahma, Y.F., \& Nugroho, A.T. Yazella F.F. Frahma, Y.F., Nugroho, A.T.Agung T.N. (2019). The Rate of Land Cover Change using Landsat Data in Coal Mining Area of Sawah Lunto City, Indonesia. Jurnal Penelitian Fisika dan Aplikasinya (JPFA). 9 (2), 189-203.

Eddy, S. \& Mutiara, D. dan Dian M. (2018). Dinamika Tutupan Lahan Kawasan Hutan Lindung Air Telang Menggunakan teknik Overlay Multitemporal. Sainmatika: Jurnal Ilmiah Matematika dan Ilmu Pengetahuan Alam. 15(2). DOI: 10.31851/sainmatika/v15i2/2179. p-ISSN $1829586 X 96 e$ ISSN 2581-0170.

Gaohong, Yin, Mariethoz, G., \& McCabe, M.F. (2017). Gap-Filling of Landsat 7 Imagery Using the Direct Sampling Method. Remote Sens, 9(1), 12. DOI: 10.3390/rs9010012.

Hadi, B. S. (2008). Strategi Pembelajaran Penginderaan Jauh Sebagai Pencitra Permukaan Bumi Berbasis Kompetensi. Jurnal Geomedia, 6 (2): 107-117.

Hidayat, F. 2014. Optimalisasi Penggunaan Lahan untuk Pengembangan Sumberdaya Air DAS Mahat Hulu di Kabupaten Lima Puluh Kota Sumatera Barat. Disertasi. Sekolah Pascasarjana. Institut Pertanian Bogor. Bogor.

Irawan, S. \& Sirait, J. (2017). Perubahan Kerapatan Vegetasi Menggunakan Citra LandsatLandsat 8 di Kota Batam Berbasis Web. Jurnal Kelautan, 10(2), 174-184.

Kamusoko, C., Aniya, M., Bongo, A., \& Manjoro, MAdi B., Manjoro M. (2009). Rural sustainability under threat in Zimbabwesimulation of future land use/cover changes in the Bindura District based on the markov-cellular automata model. Appl. Geogr, 29(3):435-447.

Kasim, F. (2012). Pendekatan Beberapa Metode dalam Monitoring Perubahan Garis Pantai Menggunakan Dataset Penginderaan Jauh LandsatLandsat dan SIG. Jurnal Ilmiah Agropolitan, 5(1), 620-635.

Kurniawan, A. (2020). Monitoring Perubahan Pola Alur Sungai Menggunakan Citra Satelit Resolusi Spasial Menengah Berbasis Spectral Classification. Jurnal Nasional Teknologi Terapan, 13(1): 1 - 12. DOI: 10.22146/jntt.56613.

Langley, S.K., Cheshire, H.M. Cheshire, \& Humes, K.S. Humes. (2001). A comparison of single date and 
multitemporal satellite image classifications in a semi-arid grassland. J. Arid Environ, 49, 401-411.

Lusyi, I., Suwarni, N., Miswar, D., Jaya, M.T.B.S.Nani S., Dedy M., M. Thoha B. S. (2020). Pemodelan Bencana Longsor Berbasis Spasial. La Geografia, 19 (1): 16-27. P-ISSN: 1412-8187 e-ISSN: 2655-1284.

Masek, J.G., Wulder, M.A., Wulder, Markham, B., .L. Markham, McCorkel, J., Crawford C.J., Storey, J., Jenstorm, Del T McCorkel, Crawford, C.J. Crawford, Storey, J.C. Storey, and \& Jenstrom, D.T. . Jenstrom. (2020). Landsat 9: Empowering Open Science and Applications Through Continuity. Remote Sensing of Environment 248. DOI: 10.1016/j.rse.2020.111968.

Megandana, H. (2013). Perubahan Penutupan Lahan di DAS Citarum Hulu - Jawa Barat dengan Menggunakan Citra Satelit Landsat ETM+. Skripsi. Departemen Manajemen Hutan Fakultas Kehutanan Institut Pertanian Bogor. Bogor.

Nordberg, M.L., J. Evertson, J.. (2005). Vegetation index differencing and linear regression for change detection in a Swedish mountain range using LandsatLandsat $\mathrm{TM}^{\oplus}$ and $\mathrm{ETM}+{ }^{\oplus}$ imagery. Land Degrad. Dev, 16, 139-149.

Nugroho, F. S. (2015). Pengaruh Jumlah Saluran Spektral, Korelasi Antar Saluran Spektral dan Jumlah Kelas Objek Terhadap Akurasi Klasifikasi Penutup Lahan. Jurnal Ilmiah Geomatika, 21(1): 163-170.

Paryono, Sukoraharjo, S.S., Damar, A., Susilo, S.B., Dahuri, R, Suseno, H. Sri S.S., Ario D., Setyo B.S., Rokhim D., \& Heny S. (2016). Analysis Dinamika Spasial dan Temporal Penggunaan Lahan dan Implikasinya terhadap Sedimentasi di Wilayah Pesisir DAS Citarum. Jurnal Kelautan Nasional, 11(3):189-200.

Petit, C., Scudder, T, \& Lambin, E. (2001). Quantifying Processes of Land-cover Change by Remote Sensing: Resettlement and Rapid Land-cover Changes in South-eastern Zambia. International Journal Remote Sensing, 22(17): 3435-3456.

Prasena, A., D. B. P. Shrestha, D.B.P., (2013). Assessing the effects of land-use change on runoff in Bedog Sub Watershed Yogyakarta. Indonesian Journal of Geography, 45(1), 48-61.

Purwanto, A.D. \& Ardli, E.R. (2020). Development of A Simple Method for Detecting Mangrove Using Free Open Source Software. Jurnal Segara, 16(2): 71-82. DOI: 10.155778/segara.v16i2.7512.

Ridwan F., Ardiansyah, M., \& Gandasasmita, K.M. Ardiansyah, \& Komarsa G. (2017). Pemodelan Perubahan Penutupan/Penggunaan Lahan dengan Pendekatan Artificial Neural Network dan Logistic Regression (Studi Kasus: DAS Citarum, Jawa Barat). Buletin Tanah dan Lahan, 1(1): 30-36.

Romiyanto, Barus, B., \& Sudadi, U. (2015). Model Spasial Kerusakan Lahan dan Pencemaran Air akibat Kegiatan Pertambangan Emas Tanpa Izin di Daerah Aliran Sungai Raya, Kalimantan Barat. Jurnal Tanah dan Lingkungan, 17(2), 47-53.

Salgado, C.B., de Carvalho, O.A., Gomes, R.A.T., Guimaraes, R.F. (2019). Cloud Interference Analysis in the Classification of MODIS-NDVI Temporal Series in the Amazon Region, Municipality of Capixaba, Acre Brazil. Sociedade \& Natureza, 31. DOI: $10.14393 / \mathrm{SN}$ -v31-2019-47062.
Salim, A.G., Dharmawan, I Wayan SI Wayan S.D.., \& Budi H.N.Narendra, B.H. (2019). Pengaruh Perubahan Luas Tutupan Lahan Hutan terhadap Karakteristik Hidrologi DAS Citarum Hulu. Jurnal Ilmu Lingkungan, 17(2), 333-340. ISSN 1829-8907.

Siliwangi, Bani. (2014). Perusakan Lingkungan akibat Alih Fungsi Kawasan Hutan di Hulu Sungai Citarum menjadi Kawasan Pertanian Dihubungkan dengan Undang-Undang Nomor 32 Tahun 2009 tentang Perlindungan dan Pengelolaan Lingkungan Hidup. Jurnal Wawasan Hukum, 30(1).

Suwargana, N. (2013). Resolusi Spasial, Temporal, dan Spektral pada Citra Satelit Landsat, Spot, dan Ikonos. Jurnal Ilmiah Widya, 1(2): 167-174. ISSN 23376686, ISSN-L 2338-3321.

U.S. Geological Survey. (2016). Landsat-Earth Observation Satellites (ver. 1.2, April 2020). : U.S. Geological Survey Fact Sheet, 2015-3081, 4 p. DOI: 10.3133/ fs 20153081 .

USGS. 2016. Landsat 8 (L8) Data Users Handbook. Department of Interior U.S. Geological Survey. South Dakota.

Wang, X., Song, G., Leus, R., Han, C. (2019). Robust Earth Observation Satellite Schedulling with Uncertainty of Cloud Coverage. IEEE Transactions on Aerospace and Electronic Systems. Preprint. DOI: 10.1109/ TAES.2019.2947978.

Yusuf, S.M., Murtilaksono, K., Hidayat, Y., \& Suharnoto Y.Kukuh M., Yayat H., \& Yuli S. (2018). Analisis dan Prediksi Perubahan Tutupan Lahan di DAS Citarum Hulu. JPSL Jurnal Pengelolaan Sumberdaya Alam dan Lingkungan, 8(3), 365-375. DOI: 10.29244/jpsl.8.3.365-375. ISSN 2086-4639. E-ISSN 2460-5824. 